\title{
Structured Simulation-Based Training Programs: History and Lessons Learned
}

\author{
Theodore M. Shlechter and Dorothy L. Finley \\ U.S. Army Research Institute
}

Armored Forces Research Unit

Barbara A. Black, Chief

U.S. Army Research Institute for the Behavioral and Social Sciences 5001 Eisenhower Avenue, Alexandria, Virginia 22333-5600

April 2000 